\title{
Neither Seen nor Said: Foucault's Experiments in Anonymity
}

\section{Laura Hengehold}

From his approval of Beckett's “what matter who's speaking?” as an ethics for literature to his late suggestion that modern power struggles may demand that we "refuse who we are," Foucault tended to regard anonymity as a condition of possibility rather than a loss. ${ }^{1}$ Most of Foucault's comments about anonymity arise in the context of his critique of phenomenology and his reflections on the political economy of discourse, that is, the way in which commentary, authorship, and the bureaucratic "case" or "dossier" shape struggles for social power. In what follows, I try to develop the implicit logic in these references to anonymity; first, with respect to language and visibility as components of phenomenal experience and, secondly, with respect to the ethical valorization of "thinking" in late twentieth century French thought.

I argue that Foucault provokes an experience of anonymity in thinking by staging an antagonism between seeing and saying. However, this anonymity cannot be equated with the anonymity of the historical or transcendental forms in which language or vision are conveyed. The anonymity of thinking arises from the thinker's gradual separation from a repetition that confronts him or her as a single event, not from the confrontation of visible with invisible. There is an ethical dimension to thinking, understood in this way, because the One that is anonymous in any individualizing apparatus of power and knowledge is the One that retains its mobility with respect to conflicts over recognition or failures of recognition. 


\section{NEITHER SEEN NOR SAID}

Several authors, most notably Gilles Deleuze (1988), have commented on the way in which Foucault's descriptions of historical phenomena focus on specific intersections between systems of discourse and systems of visibility or corporeal power. ${ }^{2}$ For example, medical discourse regarding madness in the Classical period was almost completely divorced from madness as grasped by administrative perception and treatment of the mad (Foucault 2006, Part II). Tuke and Pinel transformed the asylum into a space in which discourse and treatment could form a single proto-scientific experience (Freud added the patient's discourse to that of the physician or theorist at the end of the nineteenth century) (339). In Birth of the Clinic (1973), the physical space of the clinic enabled young doctors to visually represent the diseases whose essences they were taught in speech and writing. The precise distribution of visibility and invisibility characterizing "examination" in nineteenth century prisons created a moral and psychological identification between criminals and their case histories (Foucault 1977a, 187-192). ${ }^{3}$ Finally, the school, bourgeois home, urban environment, and colonial government made bodies visible, tangible, and articulate in ways that facilitated the deployment of sexualizing discourse (Foucault 1978).

One can understand the intersection of "seeing" and "saying" as a transcendental condition for the possibility of experience, or as a radically historical contingency. Moreover, one can study these phenomena with an eye to the identities and objects whose experience they make possible, or with respect to the indeterminate and anonymous forces brought into play when visibility and discourse fail to intersect. While this paper considers each of these options in turn, it does so to pose a question: what is the ethical value of Foucault's efforts to detach visibility and discourse as distinct modes of being from the human who is one of their effects?

\section{Seeing and Saying: Phenomenology}

Foucault's first published essay, the introduction to Binswanger's Dream and Existence (1986), compared Husserlian and Freudian accounts of the relationship between images and their verbal meaning or interpretation. There, he argued that "sense" could only be explained on the basis of a single movement of existence (68). Thus initially Foucault was in agreement with his teacher, Maurice 


\section{LAURA HENGEHOLD}

Merleau-Ponty, for whom human being-in-the-world had a fundamentally perceptual and expressive function. In Phenomenology of Perception (1962), Merleau-Ponty “corporealized" Husserl's search for transcendental, impersonal structures implicit in the experience of every knowing subject. He referred to the bodily, historical, intersubjective ontology of human being as "anonymous" (448-453); and elsewhere, as the "flesh of the world." Thought mediates a fundamental ontological unity between the seeing eye and the thing seen, a unity first disclosed by the media of painting and speaking (1968).

However, Foucault's History of Madness and Birth of the Clinic are attentive to the moments when the media of seeing and saying clash or fail to communicate, as well as those in which they contribute to a unified experience. Foucault tried to show that vision and speech coincide only when specific historical factors and institutions are present (Shapiro 2003, 234). His hesitancy to take the phenomenological case in which sense rather than nonsense emerges from seeing and saying as the norm is most famously presented in the description of Las Meninas from The Order of Things.

The relation of language to painting is an infinite relation. It is not that words are imperfect, or that, when confronted by the visible, they prove insuperably inadequate. Neither can be reduced to the other's terms; it is in vain that we say what we see; what we see never resides in what we say... And the proper name, in this particular context, is merely an artifice; it gives us a finger to point with, in other words, to pass surreptitiously from the space where one speaks to the space where one looks; in other words, to fold one over the other as though they were equivalents. $(1970,9)$

According to Gary Shapiro, Foucault's analysis of Las Meninas is a response to specific criticisms of Malraux made in Merleau-Ponty's "Indirect Language and the Voices of Silence" (1964). The Order of Things presents an explicit challenge to Merleau-Ponty's faith that the anonymity of the visible and the articulable join all seers and thinkers in a single flesh, albeit one that has pockets of privacy and obscurity. It also supports Malraux's assertion that the existential significance of painting has changed historically because of the rise of institutions like museums. 


\section{NEITHER SEEN NOR SAID}

Although he does not read Foucault as a phenomenologist and is more attentive to the historical than the existential dimension of seeing and saying, Deleuze also believes that Foucault's account of these media is "transcendental." According to Deleuze, systems of visibility and discursive formations are parallel but non-communicating forms of receptivity and spontaneity to be found in every historical institution (1988, 33-34). For example, penal law would be the form of expression or spontaneity, and the prison the form of content or receptivity, both of which form an "abstract machine" or "diagram" an immanent cause of specific historical phenomena within a society (47). But Deleuze also argues that the abstract machine of vision and discourse is a way of organizing the forces available to that society. He analogizes Foucault to a neo-Kantian, for whom discourse takes the place of understanding, visibility takes the place of intuition, and "power" plays the role of transcendental imagination unifying the two forms (and their forces) (60-61). He also reads Foucault very much in light of his own efforts to explain the genesis of sense (in Logic of Sense and $A$ Thousand Plateaus) on the basis of impersonal singularities organized into non-communicating and nonsensical series such as consciousness and corporeality; a project he refers to as "transcendental empiricism." Working in tandem, these series nonetheless permit incorporeal, "virtual" events to be incarnated in actual conscious bodies.

Deleuze's account is too complex and rich to be dealt with here in any greater detail. Let it suffice to note that he makes Foucault an ally in his own empiricist effort to wrest the tradition of transcendental philosophy away from phenomenology. Foucault, on the other hand, seems to take a more bistorical approach to language and light, regarding their independence as no less contingent than their coincidence. In The Order of Things, Foucault argues that the phenomenologist's faith in the "natural" coimplication of expression and sensibility reflects the historical development of European ideas regarding language. In the classical era, light and language were ideally linked in a common system of representation. The Classical period and nineteenth century also assumed that language and the perceptual world coincided because of an obvious identity between the subject of "I think" and the subject of "I speak." This system began to break down when Kant situated conditions for the possibility of representation in the finite human subject (rather than in divine knowledge or power). It shifted further in the middle of the nineteenth century when the subject of "I think" 


\section{LAURA HENGEHOLD}

was equated with the subjects of "I work" and "I live" as well as "I speak." Phenomenology, the critical self-knowledge of a working, embodied, linguistic cogito, is a product of this shift, which gave rise to our robust notion of "man."

The tripartite cogito of humanism suffered a blow, however, when modern literature detached the "I speak" from the "I think" and demonstrated its autonomous existence (1970, 305-307). This was a major disruption to the nineteenth century episteme, for "in Western culture the being of man and the being of language have never, at any time, been able to coexist and to articulate themselves one upon the other" (339). Once detached from the content of discourse, moreover, the self-referential "I speak" lacks specificity. ${ }^{4}$ This is the nonphenomenological reason Foucault continues to refers to discourse as anonymous. In his literary essays of the 1970s, Foucault frequently refers to a "murmur" in the background of representation (e.g., 1977b, 138), and at the end of Discipline and Punish, he claims that we "must hear the distant roar of battle" beneath "this central and centralized humanity, the effect and instrument of complex power relations, bodies, and forces" (1977b, 308). In sum, the anonymous "being of language" is discovered as a result of historical shifts in the structure of discourse, and lacks any transcendental status across epochs. ${ }^{5}$

Although The Order of Things began by evoking the specific disabilities of description when faced with painting, it is true that Foucault ends up replacing the being of man with the being of language rather than the being of the visible, a situation which continues in The Archeology of Knowledge. Is there an anonymous "I see," a glimmering being of the visible comparable to the murmuring being of language? Does it also have an autonomous historical development?

The most obvious examples of the anonymous "I see" are the gaze incarnate in the clinic and the panoptical observer implicit in carceral systems. But the representation of natural kinds or essences in the Classical era relied on botanical gardens, dictionaries, encyclopedias, and physical or artistic representations of wealth (an important function of modern easel painting was the representation of wealth). In the nineteenth century, these representations suffered their own Copernican turn toward the viewer's/painter's subjectivity that can be compared to the formation of a transcendental-empirical doublet in the order of discourse. The self-portraits of Van Gogh and Cézanne, which Merleau-Ponty regards as exemplars of the painter's 
vocation, evoke a world in which seeing, feeling, and expression are seamlessly interwoven (Shapiro 2003, 241). But architectural and administrative innovations also encouraged observers to identify light with the visibility of the laboring, speaking, or living individual - as in the post-revolutionary teaching clinic, the prison, and eighteenth century techniques for mapping the movements of disease and wealth within large populations. Just as the being of language was concealed by the Classical system of representation and then by humanism, so too we might say the being of the visible was concealed first by the sovereign's splendor and later by the diffuse but omnipresent gaze of a "security" oriented society.

Foucault's review of Deleuze in the essay "Theatrum Philosophicum" tells us as much about his own understanding of the relation of "I think" and "I see" as the book Foucault tells us about Deleuze's project. Here Foucault describes the genesis of sense in terms of a break between the "I think" and the "I see," rather than, as for Mallarmé and other avant-garde writers, a break between the "I think" and the "I speak." "Stupidity is contemplated," Foucault explains, "sight penetrates its domain and becomes fascinated; it carries one gently along and its action is mimed in the abandonment of oneself; we support ourselves upon its amorphous fluidity; we await the first leap of an imperceptible difference, and blankly, without fever, we watch to see the glimmer of light return" (1977b, 189). Foucault also uses the language of a "flash" or "leap" of difference in "Thought of the Outside," where he refers to the constant retreat of the companion who represents the limit of language as a "gleaming disappearance [étincelante disparition]" $(1998,165)$. Thus vision has the capacity to be anonymous and to retreat like language.

In This is Not a Pipe, Foucault contends that Klee, Kandinsky, and Magritte represent a breakdown in the assumption that images are different in kind from words and can be named with words. However, he also gestures toward a different relation between the "I think" and the "I see" in the pop art of Andy Warhol. "A day will come when, by means of similitude relayed indefinitely along the length of a series, the image itself, along with the name it bears, will lose its identity" $(1983,54)$. This suggests a further parallelism between the being of language and the being of the visible: both are to be understood in terms of multiplicities or forms of repetition rather than in terms of expression. In The Archeology of Knowledge, Foucault tried to understand 


\section{LAURA HENGEHOLD}

discourse in terms of énoncés or singular linguistic events subject to material instantiation in the statements and subject positions of various speakers. So, too, the multiplication of images in a single artwork by Warhol foregrounds the anonymity of car crash participants and of Marilyn Monroe beneath her over-exposed, all-too-often-repeated smile. Stupidity or slumber are transformed into alertness when an image or experience is repeated so many times, as in Warhol's serial prints, that the experience is one of a repetitive event rather than the recognition of a content.

\section{Voice, Gaze, Thought}

In many ways, Foucault's inquiry into the distinct nature of visible and articulable formations participates in a general turn toward the genesis of sense and the conditions for genuine "thinking." In Thinking Through French Pbilosopby (2003), Len Lawlor argues that these questions dominated French thought in the 1960s. Toward the end of The Order of Things, for example, Foucault refers to the disappearance of man as "the unfolding of a space in which it is once more possible to think" (Foucault 1970, 342). ${ }^{6}$ In this endeavor, Derrida, Deleuze, and Foucault were preceded by Heidegger, whose own attempt to liberate thinking [Denken] from philosophy (understood as a metaphysics of presence) emerged from a critique of the individual's immersion in the everyday concerns of an anonymous "they" or "das Man." Foucault and Deleuze were also influenced by Blanchot and Bataille, who differed from Heidegger in regarding confrontation with death as a liberatory loss of identity rather than a singularizing, authenticating encounter. Lawlor argues that their interest in thinking emerged from a common concern with the priority of language over individual phenomenological moments in Hegel's Phenomenology of Spirit, especially as explicated by Jean Hyppolite (Hyppolite 1997).

However, I think that the author most helpful for understanding the ethical value of anonymity in Foucault's struggle to "think" is Jacques Lacan, for whom subjectivity is always constructed in response to the senseless provocation of being visible and vulnerable to the other's voice. ${ }^{7}$ In several essays from Ecrits and again in Seminaire XI, Lacan explains that children are both reassured and unsettled by their visibility and subjection to the other's (often) incomprehensible verbal demands. Subjects adopt an appearance and take up an identity in language to 


\section{NEITHER SEEN NOR SAID}

camouflage and protect themselves against the viewer's or interlocutor's aggression, as well as to disconcert others in return. However, we are only intermittently the objects of others' attention; the desire for reassurance leads us to fantasize that the gaze and intention of other speakers/watchers are more consistent and totalizing than is actually the case.

Both Merleau-Ponty and Lacan make reference to a story by Pliny the Elder, in which the trompe l'oeil artist Parrhasios painted an extraordinarily realistic curtain. This performance upstaged his colleague Zeuxis, who, not realizing that this curtain was the work being exhibited, asked, "Well, and now show us what you have painted behind it?" (Lacan 1981, 103; Pliny 1962, 406-7; see also discussion in Shapiro 341-342). Why was Zeuxis taken in so easily? According to Lacan, the viewer encounters actual objects of sight and is the object of others' vision, but he or she expects and desires "more" behind the veil as a condition for the unity of experience. We imagine that someone who encounters us confronts a psychic totality (the mor), and we listen carefully to the tone of a spoken or written comment in order to divine its true intention. Gaze and voice are like Ideas of reason orienting Kant's sensibility and understanding in their formation of an implicitly total experience. Lacan conjectures that the psychic function of painting is to attract curiosity - the desire to "see more" and to "keep looking" while assuring viewers at the same time that they are seeing everything and need not further scrutinize the artwork or painter. Likewise, music attempts to capture and humanize the uncanny tone that supplements speech or written discourse but never announces itself in words (Dolar 1996).

However, the "more" or "everything" does not exist apart from the subject's desire. The desire to think, see, or hear everything is a desire to stand in the place of the object, to "see myself seeing myself" or hear the inner intention of the voice by which someone else affects me. Lacan tells a story of his experience on a fishing boat as a student, when a fisherman who was unimpressed with his visitor's educational credentials pointed to a sardine can flashing on the water: "You see that sardine can? Well, it doesn't see you!" $(1981,95)$. Here, the fisherman deflates Lacan's desire as well as his narcissistic camouflage by revealing the inconsistency and insubstantiality of the object of his gaze. Holbein creates a similarly ironic effect when he fills in the viewer's 


\section{LAURA HENGEHOLD}

desire to "see more" and make sense of The Ambassadors as a totality by adding a death's head to the bottom of the painting that can only be seen from a difficult angle.

Each of the twentieth-century French philosophers Lawlor examines from the perspective of "thinking" demonstrates a different configuration of fantasies regarding gaze and voice. Derrida, for example, examines the apparent self-presence of thought as an act of speaking to oneself and finds that in every case of thinking, there is a split between the one who speaks and the one who listens. Sense is made possible by the trace of past reception or future utterance in every present enunciation. Thus thinking arises because we are capable of standing outside our own thought, relating to it in a protective fashion as the speech of the other. In trying to understand the intentions of the other, conversely, we are restricted to elaborating our own interior doubleness, fold, or doublure, which leaves us in a state of perpetual indebtedness or hauntedness by alterity.

Deleuze, on the other hand, describes the genesis of thinking as neither visual nor discursive, but arising between these two elements:

In the field of knowledge as problem thinking is ... carried out in the space between the two, in the interstice or disjunction between seeing and speaking. On each occasion it invents the interlocking, firing an arrow from the one towards the target of the other, creating a flash of light in the midst of words, or unleashing a cry in the midst of visible things. Thinking makes both seeing and speaking attain their individual limits, such that the two are the common limit that both separates and links them. (Deleuze 1988, 116-7)

The two series, discursive and visible, determining and determinable, are different in kind and precede consciousness rather than being interior to the structure of consciousness.

But thinking links the two differently than ordinary phenomenological experience does. According to Lawlor, these strata become recognizably independent when a senseless question is put to a subject of light and language, demanding an inventive response. For example, the medieval judicial system produced language that would be regarded as true in response to the extreme sensations of torture, and the interrogator invoked in The History of Sexuality tells his captive to rewrite his confession, "and tell the truth" $(1978,61)$. "Thinking 
begins in silence," Lawlor writes, "when no longer relying on the voice of others - they are silenced - one begins to respond in one voice, the voice of everyone or no-one: On. Then the transmutation of powerlessness into power occurs: one invents a response to the question" $(2003,137)$.

However, as explained above, the audience's demand to "see more" or the torturer's demand to "hear the whole truth" are only credible if the victim him or herself wants to believe that there is a single totalizing place from which experience can be comprehended. In the Deleuze scenario, thought is provoked by the prisoner's inability to escape his interrogator's sadistic demand. In the Derrida scenario, thought responds to the feeling of powerlessness at one's inability to sufficiently recognize the Other (who eludes the schema of recognition and thereby opens a horizon). The fantasmatic element in these scenarios is the presumption of the Other's total control or total elusiveness.

In driving an analytic wedge between the elements of a power situation which make objects recognizably perceptible and those which assign names to what is perceived, Foucault seems to be following Lacan. ${ }^{8}$ Foucault's texts suggest that the desire of/for the gaze and the desire of/for the voice reinforce one another and fill in one another's lacunae. For example, art critics and journalists become adept at supplementing a disturbingly incomprehensible "picture" with verbal explanation, and teachers frequently draw a diagram on the board if students remain confused by what has been said, as if that were to satisfy the need built up by repeated promises of clarity. Merleau-Ponty's faith in the inexhaustibility and unity of the perceptual world exemplifies the fantasy of existing for an all-encompassing gaze. Perhaps this structure gives rise to experience; Foucault questions whether it may also inhibit thought. Although Blanchot's Orpheus is consumed by desire to see the inaccessible face of his beloved and Ulysses has himself tied himself to the ship's mast in order to survive the Sirens' music, neither gaze nor voice need be sources of torture or longing. They must be "seen through" and disobeyed - either voluntarily or accidentally, when repetition of a phrase or image leads to awareness of its senselessness.

Barbara Kruger's photo-collage "Untitled (You are not yourself)" illustrates this challenge (Kruger 1990, 31). The artwork depicts a broken mirror reflecting a woman's face. However, the image 


\section{LAURA HENGEHOLD}

of her face is also "broken" with the fragments, rather than reflected in them as a separate whole. The fragments evoke a sense of loss in the viewer, a loss exacerbated by codes urging women to identify themselves with their physical appearance. But Kruger's piece also reminds viewers that they are, in fact, neither the image visible to themselves and others nor the name or pronoun (you) through which others affect them. The point is hardly that viewers are or ought to become broken images or stammering voices. This work makes neither a knowledge claim nor a normative claim about the viewer, but engages in a critical act - detaching the viewer, especially the female viewer, from the images and pronouns through which women in a consumer culture envision and explain their existence to themselves.

\section{Totality and Recognition}

What happens in this flash, separation, or experience of being "outside" one's thought and perception? Who survives or witnesses the effacement of man like a face traced in sand, or the breaking of Barbara Kruger's mirror? According to Deleuze, Nietzsche's crucial question when confronted with a phenomenon is "Which one is it? ...the question 'which one?' $[q u]$ means this: what are the forces which take hold of a given thing, what is the will that possesses it?" (1983, 77).

Shapiro draws attention to Foucault's rhetorical creation of a "we-subject" capable of identifying, through several repeated passes, the dynamics of vision and identification at work in Las Meninas (2003, 251-263). The unity of this fictive "we" sustains us through an analysis of representation that strictly speaking rules out any solid faith in a common perception. However, at a certain point in his narrative, Foucault stops talking about "we" the viewers and refers to the viewer who used to believe in the integrity of representation as "one." "It is in vain that we say what we see..." but "if one wishes to keep the relationship of language to vision open, if one wishes to treat their incompatibility as a starting-point for speech instead of as an obstacle to be avoided... then one must erase those proper names and preserve the infinity of the task" (1970, 9-10). In this passage, Foucault plays language against visibility, using a linguistic mask to support the reader as he or she learns that language does not refer unproblematically to 


\section{NEITHER SEEN NOR SAID}

vision, and that vision does not necessarily show us things that can be named.

Often Foucault contends that the "one" who speaks in language is language itself, just as the "one" who sees the image is the subject of another image in his or her own right. Interviews from the seventies suggested that strategies of power are composed of "subindividuals" (1977c, 208) or that they are subtended by a "plebeian quality" (137-8). Another potential candidate for the anonymous "one" from which relations of power and knowledge emerge are the "subjugated knowledges" pushed aside in the Enlightenment consolidation of scholarly disciplines. ${ }^{9}$ Deleuze analyzes the outside of Foucault's historical diagrams in terms of "forces" $(1988,113)$. But in the chapter on subjectivation, Deleuze also gives stage names to the ways in which the "thing that thinks" can fold or recombine those forces in resistance to the present, such as "a Greek" or "a Christian" (119).

The early essay "What is an Author?" is one of many places where Foucault challenges the immediate impulse to offer a definite answer to the question "who?" Foucault cited Samuel Beckett's indifferent question "what matter who's speaking?” [“qu'importe qui parle?'] as a fundamental ethical principle for modern literature (1977b, 115-116). In the late 1950s and early 1960s modernist authors like Mallarmé, Artaud, and Beckett provoked critical interest in écriture as a practice or field of textual production rather than the expression of psychic interiority. Foucault worried, however, that "écriture" as a field of discourse, supposedly independent of authorial intention, might be misinterpreted in terms of the empirical features of valorized authors, reinstituting "a transcendental anonymity" ["anonymat transcendental"] (119-120). ${ }^{10} \mathrm{He}$ cautions against pasting a new "cogito" or "man" over the being of language once the "I speak" and the "I think" have come apart - a gesture that would be comparable to reassembling Kruger's shattered mirror with tape and glue. This ethos is articulated negatively in the introduction to Archaeology of Knowledge: "I am no doubt not the only one who writes in order to have no face. Do not ask who I am and do not ask me to remain the same: leave it to our bureaucrats and our police to see that our papers are in order. At least spare us their morality when we write" $(1972,17)$. In the early 80 s, his formulation is succinct: "Maybe the target nowadays is not to discover what we are but to refuse what we are" $(1997,336) .{ }^{11}$ 


\section{LAURA HENGEHOLD}

"What is an Author?" is only one of several texts, therefore, in which Foucault questions the role played by the desire for a totalizing gaze or ear in organizing the political economy of discourse. Along with authorship, he challenges genres that tie self-understanding to an all-seeing or comprehensively descriptive discourse such as "commentary," the "case study," and intellectual polemics. The practice of commentary restricts the topics of scholarly production to those which have already been authorized and ties new speech or writing to the elaboration of older authorial names. Foucault is fascinated by the traces of lives such as those of seventeenth-century prisoners found only in archives, but he also questions the conditions under which formerly anonymous peasants and townspeople, unheard by those in power, gradually became the subject matter of individualizing "cases" with the spread of modern social science and administration (1977a, 191-193). In a late interview on the proper conduct of intellectual debate, he explicitly questions the strategy of identification with an existing moral position because of its restricting effects:

the problem is, precisely, to decide if it is actually suitable to place oneself within a "we" in order to assert the principles one recognizes and the values one accepts; or if it is not, rather, necessary to make the future formation of a "we" possible, by elaborating the question. Because it seems to me that the "we" must not be previous to the question; it can only be the result - and the necessarily temporary result - of the question as it is posed in the new terms in which one formulates it. (Foucault 1984, 385)

Why this reluctance to name the one who thinks? Why is it an ethical issue? Perhaps we get a clue from Foucault's inaugural address at the Collège de France. At the beginning and end of this lecture (which quotes again from Beckett), Foucault describes a remarkable fantasy of dissociation from his own voice, which he would prefer to hear as the voice of his teacher and predecessor in this academic chair, Jean Hyppolite.

I would really like to have slipped imperceptibly into this lecture, ... to have perceived a nameless voice, long preceding me, leaving me merely to enmesh myself in it, taking up its cadence, and to lodge myself, when no one was looking, in its interstices as if it had paused an instant, 


\section{NEITHER SEEN NOR SAID}

in suspense, to beckon to me. There would have been no beginnings; instead, speech would proceed from me, while I stood in its path — a slendergap — the point of its possible disappearance.” (1972a, 215) ${ }^{12}$

Discourse is a risky environment, he explains in the body of his presentation. Although institutions try to neutralize language, limiting the number of speakers and statements through mechanisms like the exclusion of falsehood, rarefaction and organization of statements, and social authorization of speakers, "speech is no mere verbalisation of conflicts and systems of domination, but... the very object of man's conflicts" (1972a, 216). To begin to speak opens a confrontation between voices and perceivers, a claim on the gaze and hearing of others. The muses fight over their shared tongue just as the Gorgons fought over their single communal eye.

Of course, Hegel is not only the subject of Hyppolite's major works but the historical thinker most identified with "struggles for recognition." ${ }^{\prime 3}$ In Nietzsche and Philosopby, Deleuze suggested that the "one" that really wills in the will to power only gets into Hegelian conflicts for recognition because it conceives power as the object of a representation (1983, 80-82). ${ }^{14}$ From "Thought of the Outside" and The Order of Things, however, we learned that representation broke down when the being of language became unglued from the "I think," and when the repetition of famous faces, images of highway disaster or consumer logos become events in their own right. When language ceased to be the medium of representation, in other words, it could no longer be the object of conflict in the same way as before. Foucault connects this breakdown with the resumption of thinking. In Lacanian terms, thought is not provoked by the violently physical demand or the ghostly appeal of an Other, but by the demonstration that the voice lacks consistency in its reference to the perceptual dimension (or vice versa).

I choose to read Foucault's critiques of authorship as reflecting curiosity as to how intellectual exchange might function in the absence of competitive mechanisms for recognition. This strategy enables us to see the continuity between early essays like "What is an Author" and the Foucault's later skepticism with regard to intellectual polemics which lead to a winner-take-all economy of public discourse. "If I have chosen anonymity," he explained elsewhere, "it is not... to criticize this or that individual, which I never do. It's a way of addressing the potential reader, the only individual here who is of interest to me, more directly: 


\title{
LAURA HENGEHOLD
}

'Since you don't know who I am, you will be more inclined to find out why I say what you read; just allow yourself to say, quite simply, it's true, it's false. I like it or I don't like it' $(1988,325)$.

Foucault praises Hyppolite for reinterpreting Hegel's claim to absolute knowledge as a single "event" emerging like a light glimmering between repeated acts of interrogation, rather than the accomplishment of a totalizing gaze $(1994,780)$. The "one" who experiences this flash or hears the murmur is by definition always potentially plural, without being a definite "we." In his analysis of the painting "Les Deux Mystères," Foucault shows how the simulacra that replace a simple statement of affirmation or negation regarding the presence of a pipe immediately multiply:

\begin{abstract}
"None of these is a pipe, but rather a text that simulates a pipe; a drawing of a pipe that simulates a drawing of a pipe; a pipe (drawn other than as a drawing) that is the simulacrum of a pipe (drawn after a pipe that itself would be other than a drawing)." Seven discourses in a single statement - more than enough to demolish the fortress where similitude was held prisoner to the assertion of resemblance. $(1983,49)$
\end{abstract}

A simulacrum is neither original nor derivative, but differs in a way that is incomparable and therefore incapable of facing off against others in a unifying fantasy of recognition. Each of these simulacra will have proven to not be a pipe in its own way, but each also defines itself through "tilting and tumbling" against the others (46). Likewise, in "Thought of the Outside," Foucault refers to the companion who represents the attraction of thought's limit (the pure "it speaks" in every "I speak") as a double, but the servants who take on this ambiguous role in Blanchot's novels are plural $(1998,163)$. Many speak, in other words, behind the "I speak;" anonymous being is neither one nor more than one. ${ }^{15}$ When Deleuze describes the process by which the Greeks "folded" or acted on their own actions with respect to the anonymous one, he draws attention to the importance of agonism in Foucault's image of the Greeks $(1998,101)$. What we must preserve from Hegel's scene of struggle between two would-be masters is the intensity and affect of struggle, while the unity of any possible scene of recognition dissolves, revealed as an effect of the gaze. 


\section{NEITHER SEEN NOR SAID}

My goal here has been to outline the historical, libidinal, and ethical stakes in Foucault's many references to anonymity. Where Deleuze offers a transcendental empiricist reading of light and language, certainly with ample support from Foucault, I have focused on the anonymity of the "one" who is released when light and language lose their power to fascinate and command the speaking, visible subject. I think the project of identifying events from within a chain of repetitions that come to lose their sense and from which thought then separates itself in a flash is more characteristic of Foucault's long-term intellectual interest. It may (though this is less certain) differentiate Foucault's understanding of the genesis of thinking from the more violent account of how Deleuzian thinking originates, given by Lawlor in Thinking Through French Philosophy. Finally, I give priority to the critical task of getting free from one's verbal and imaginary identifications, without immediately speculating on the nature of the one who is freed, or trying to consolidate that difference in a new identity worthy of recognition.

Readers of French philosophy from the sixties are often alarmed that distance from phenomenological subjectivity will entail complete disappearance from the field of the gaze and voice or identification with a "multiplicitous," "schizophrenic" subject position. Barbara Kruger puts the "not" in her photocollage, "Untitled (You are not yourself)" on a small paper cut-out as if to enclose it in parentheses. Without this warning, there is a risk that viewers will conceive of the One left standing before the mirror as a broken subject, incapable of thinking. Many feminists, for example, are loath to explore poststructuralist critiques of subjectivity because they rightly value the intensity that their experience, style of vision, and speech gain from recognition and struggles for recognition (Lorraine 1999, 135-136). I have followed Foucault's comments on visibility, language, and anonymity through the maze established by Derrida, Deleuze, and Hyppolite in order to show that the intensity of the "one" who cannot be captured in a mirror image or a pronoun is anything but broken.

However, this "one" only appears on the diagonal and after much repetition and forgetfulness. The event only appears in what Foucault calls the interiority "d'attente" [waiting or expectation] in "Thought of the Outside" $(1998,167)$. It takes time, in other words, for the "one" that one is to separate from the simulacra against which it "tilts and tumbles," time in which the repetition of a useless or no 


\section{LAURA HENGEHOLD}

longer relevant action or phrase comes to seem like an obvious neurosis, transference effect, or mask from which one can eventually step aside. I suspect this "attente" is an important way to negotiate the conflicts that circulate around visibility and speech without giving up the intensity of struggle which makes recognition seem so desirable. This is the ethical lesson, if not the strictly biographical content, of Foucault's experiments in anonymity.

\section{Case Western Reserve University}

\section{Notes}

${ }^{1}$ This idea is familiar in Eastern thought but difficult for Westerners to grasp, possibly because the "Western" subject emerged alongside technologies of power that make identity a precious commodity and loss of identity a disaster.

${ }^{2}$ See Deleuze 1988, Flynn 2005, Shapiro 2003.

${ }^{3}$ See Foucault 1977c, 198: "If you take Gabriel's architectural plan for the Military School together with the actual construction of the school, who is to say what is discursive and what institutional?" From his review of Panofsky: "Le discours et la figure ont chacun leur mode d'être; mais ils entretiennent des rapports complexes et enchevêtrés" (1994, 622).

${ }^{4}$ For positive inspiration, Foucault draws on Maurice Blanchot's notion of writing as a non-expressive, impersonal practice, as well as on Bataille's description of experiences that destroy the subject's ability to engage in expression.

${ }^{5}$ For an extensive discussion of anonymity in language, see Oksala 2005, Ch. 3.

${ }^{6}$ On this theme, see also Bernauer 1990.

${ }^{7}$ See Copjec 2000. The role of the gaze and voice in human socialization are first addressed in Lacan's essays, "On the Mirror Stage" and "Subversion of the Subject "(in Lacan 1977), as well as Lacan 1981, 67-119.

${ }^{8}$ See Lane 2000 and Racevskis 1983, esp 67-95. In The Archeology of Knowledge, Foucault refers to the task of undoing "transcendental narcissism" (1972, 203).

${ }^{9}$ Indeed, Foucault suggests that the battles over institutional subjectification in the 1960s and 70s (including patients' rights, prisoners' rights, children's rights, gay rights and women's rights) represented the "return" of subjugated knowledges to a position of potential dialogue with the expert knowledges of medicine, administrative science, and psychiatry. One might compare this to the "return of language" in The Order of Things (1970, 298300). 


\section{NEITHER SEEN NOR SAID}

${ }^{10}$ Foucault expresses a similar skepticism regarding universalist epistemological standpoints that claim to be anonymous in "Nietzsche, Genealogy, History" (1977b, 158). However, in "The Discourse of History," Foucault seems to identify the anonymous element in literature with "the formal relations...not present in the mind of anyone" (1996, 20-22). Here he describes these relations as a "construction;" suggesting that he associates the anonymat with different elements of the literary experience at different moments.

${ }^{11}$ His preface to Deleuze and Guattari's Anti-Oedipus, one of the few references to ethics from the seventies, calls for 'dde-individualization' by means of multiplication and displacement (Foucault 2000, 109).

12 " $\mathrm{I}$ know now just what was so awesome [redoubtable] about beginning; for it was here, where I speak now, that I listened to that voice... where its possessor is no longer, to hear me speak" (Foucault 1972a, 237).

${ }^{13}$ Foucault's presentation of "Qu'est-ce qu'un auteur?" before the Société Français de Philosophie in 1969 also evokes the ghostly presence of Hyppolite (1994, 790).

${ }^{14}$ On this matter, and with respect to Foucault's relationship with Hegel in general, I am indebted to Brent Adkins' presentation from SPEP 2004, "Foucault and Klossowski: On the Limits of Sade."

${ }^{15}$ On “plus-qu'unité," see Gilbert Simondon (1989, 13-15).

\section{Works Cited}

Bernauer, James W. 1990. Michel Foucault's Force of Flight: Toward an Etbics for Thought. Atlantic Highlands, NJ: Humanities Press.

Copjec, Joan. 2000. "The Body as Viewing Instrument, or the Strut of Vision." In Lacan in America, ed Jean-Michel Rabaté. New York: Other Press.

Deleuze, Gilles. 1983. Nietzsche and Philosophy. Trans. Hugh Tomlinson. New York: Columbia University Press.

.1988. Foucault. Trans. and ed. Sean Hand. Minneapolis: University of Minnesota Press.

-1994. Difference and Repetition. Trans. Paul Patton. New York: Columbia University Press.

Dolar, Mladen. 1996. "The Object Voice.” In Gaze and Voice as Love Objects. Ed. Renata Salecl and Slavoj Zizek. SIC Vol. 1. Durham: Duke University Press.

Flynn. Thomas R. 2005. Sartre, Foucault, and Historical Reason: A Poststructuralist Mapping of History, Vol. 2. Chicago: Chicago University Press.

Foucault, Michel. 2006. History of Madness. Ed. Jean Khalfa, trans. Jonathan Murphy and Jean Khalfa. London: Routledge. 


\section{LAURA HENGEHOLD}

2003. "Society Must be Defended": Lectures at the College de France, 1975 -

1976. Trans. David Macey. New York: Picador.

2000. Power. Ed. James Faubion. Essential Works of Foucault 1954-

1984, Volume 3. New York: New Press.

-1998. Aesthetics, Method, and Epistemology. Ed.James Faubion. Essential

Works of Foucault 1954-1984, Volume 2. New York: New Press.

. 1996. "The Discourse of History" in Foucault Live: Interviews, 1966-

84. Trans. John Johnston, ed. Sylvère Lotringer. New York: Semiotext(e). 1994. Dits et Écrits, 1954-1988. Vol. 1. Ed. Daniel Defert and François

Ewald. Paris: Éditions Gallimard.

- 1988. Politics, Philosopby, Culture: Interviews and Other Writings, 1977-

1984. Ed. Lawrence Kritzman. New York: Routledge.

- 1986. "Dream, Imagination, and Existence." Trans. Forrest Williams.

Review of Existential Psychology and Psychiatry, Vol. XIX (1), 29-78.

. 1984. The Foucault reader. Ed. Paul Rabinow. New York: Pantheon Books.

- 1983. This is Not a Pipe. Trans. James Harkness. Berkeley: University of California Press.

1978. The History of Sexuality. Vol. I: An Introduction. Trans. Robert Hurley. New York: Vintage Books.

.1977a. Discipline and Punish: The Birth of the Prison. Trans. Alan Sheridan.

New York: Vintage Books.

. 1977b. Language, Counter-memory,Practice: Selected Essays and Interviews.

Ed. Donald F. Bouchard, trans. Donald F. Bouchard and Sherry Simon.

Ithaca: Cornell University Press. .1977c. Power/Knowledge: Selected Interviews and Other Writings, 1972-1977.

Ed. Colin Gordon; trans. Colin Gordon, Leo Marshall, John Mepham, Kate Soper. New York: Pantheon Books.

- 1973. The Birth of the Clinic: An Archaeology of Medical Perception. Trans.

A. M. Sheridan Smith. New York: Pantheon Books.

- 1972. The Archeology of Knowledge Trans. A.M. Sheridan Smith. New

York: Pantheon Books.

- 1970. The Order of Things: An Archaeology of the Human Sciences. Trans.

Alan Sheridan. New York: Random House.

Hyppolite, Jean. 1997. Logic and Existence. Trans. Leonard Lawlor and Amit

Sen. Buffalo: State University of New York Press.

Kruger, Barbara. 1990. Love for Sale: The Words and Pictures of Barbara Kruger.

Text by Kate Linker. New York: H.N. Abrams.

Lacan, Jacques. 1981. The Four Fundamental Concepts of Psychoanalysis. Trans.

Alan Sheridan. New York: W.W. Norton

1977. Écrits: A Selection. Trans. Alan Sheridan. New York: Norton.

Lane, Christopher. 2000. "The Experience of the Outside: Foucault and

Psychoanalysis." In Lacan in America, ed Jean-Michel Rabaté. New York: 


\section{NEITHER SEEN NOR SAID}

Other Press.

Lawlor, Len. 2003. Thinking Through French Philosophy. The Being of the Question. Bloomington: Indiana University Press.

Lorraine, Tamsin. 1999. Irigaray and Deleuze: Experiments in Visceral Pbilosophy. Ithaca: Cornell University Press.

Merleau-Ponty, Maurice. 1962. Phenomenology of Perception. Trans. Colin Smith. London: Routledge and Kegan Paul. . 1964. "Indirect Language and the Voices of Silence." Signs. Trans. Richard C. McCleary. Evanston: Northwestern University Press. 1968. The Visible and the Invisible, Followed by Working Notes. Ed. Claude Lefort, Trans. Alphonso Lingis. Evanston: Northwestern University Press. Oksala, Johanna. 2005. Foucault on Freedom. Cambridge: Cambridge University Press.

Pliny the Elder. 1962. Selections from The History of the World, Commonly Called The Natural History of C. Plinius Secundus. Trans. Philemon Holland, ed. Paul Turner. Carbondale: Southern Illinois University Press.

Racevskis, Karlis. 1983. Michel Foucault and the Subversion of Intellect. Ithaca: Cornell University Press.

Shapiro, Gary. 2003. Archaeologies of Vision: Foucault and Nietzsche on Seeing and Saying. Chicago: University of Chicago Press.

Simondon, Gilbert. 1989. L'Individuation psychique et collective. $A$ la lumiére des notions de forme, information, potentiel et metastabilité. Éditions Aubier. 